\title{
ELECTRONIC REGISTRATION OF SALES IN THE CZECH REPUBLIC - THEORY AND PRAXIS ${ }^{1}$
}

\author{
ZUZANA MARETHOVÁ ${ }^{2}$ PETRA SNOPKOVÁ3
}

\begin{abstract}
This contribution analyses the system of electronic registration of sales that has recently been introduced in the Czech Republic. Apart from the analysis, the paper also discusses the types of subjects that need to register their sales, the registration methods, as well as the ways to control if the law is adhered to. Moreover, the paper also deals with the objectives of the new legislation and it offers a brief analysis of what the situation is like in other countries. The paper makes use of methods of analysis, synthesis, and comparison. Analytical methods are used here to analyze the effectiveness of the new legislation and of the electronic registration of sales in the Czech Republic. Then, comparative methods are applied to compare Czech legislation with that of other countries, especially with Croatian legislation. In addition, these methods are employed to compare the expected and the real consequences of the electronic registration of sales. The gathered data is then processed by means of synthesis to outline the future of the electronic registration of sales. The paper hypothesizes that the electronic registration of sales is an effective measure against tax evasion and it thus achieves the intended objectives of the legislation.
\end{abstract}

\section{Keywords}

Tax law; registration of sales; electronic registration

\section{JEL Classification: H25, K34, O31}

1 This article is the outcome of the research projects: MUNI/A/1359/2016 (Reformation of income taxes) and MUNI/A/1387/2016 (Stabilization in financial and tax law).

2 Ph.D. Student at the Faculty of Law, Masaryk University at the Department of Financial Law and Economic. The Author specializes in tax law. Contact email: 344107@mail.muni.cz.

3 Ph.D. Student at the Faculty of Law, Masaryk University at the Department of Financial Law and Economic. The Author specializes in tax law. Contact email: snopkova@mail.muni.cz. 


\section{Electronic Registration - Basic Facts}

\subsection{Description and Legislation}

The electronic registration of sales (hereafter referred to as "registration") was introduced into Czech law by means of Act no. 112/2016 on Registration of Sales, effective from 1 December 2016 (hereafter referred to as the "Act").

Registration is a means of control ensuring that tax obligations applicable to taxable entities are fulfilled. The reason for its introduction was, above all, the desire to prevent tax evasion based on unlawful sales reduction (accepted especially in cash). Unlawful sales reduction is typically committed when a mandatory entry in the registration book states a figure lower than the actual payment. A subsequent inspection, often made several months or even years later, hardly ever reveals such sales reduction. A legal obligation to register every payment online (via the internet) with the Financial Administration of the Czech Republic (hereafter referred to as the "Financial Administration") has thus been introduced with a view to preventing such illegal manipulation (Hajdušek, Vodička, 2017).

Registration can be described in greater detail as a system within which an entrepreneur who has just accepted a payment (typically in cash) sends an instantaneous data message with the transaction details through a device connected to the internet to the Financial Administration, which subsequently sends back a confirmation of receipt with a unique code (called FIC, Fiscal Identification Code). Then, the entrepreneur issues a receipt which, among other legal requirements, also includes the given FIC. The entrepreneur is required to provide the customer with this receipt. The customer may later enter the FIC at the web portal of the Financial Administration, thereby checking that the payment has indeed been registered. Sales registered under the name of a particular entrepreneur may be checked by him or her at the web portal as well. The whole process is aptly illustrated by the following graph from the official Registration website (www.etrzby.cz). 


\section{Graph 1 System functioning of Registration}

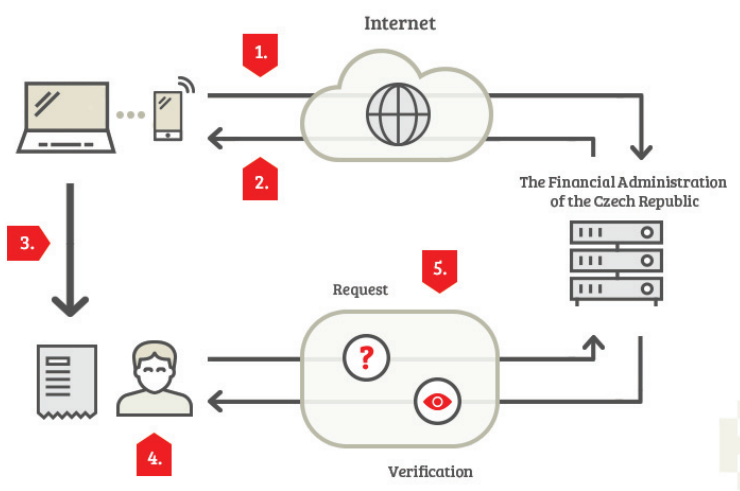

Source: www.etrzby.cz.

\subsection{Subjects of Registration}

The definition of subjects required to register sales is heavily based on Act no. 586/1992 on Income Taxes (hereafter referred to as the "Income Tax Act"). Registration is compulsory for all taxpayers of personal and corporate income tax. Taxpayers of personal income tax are natural persons: those who reside in the Czech Republic (with a permanent address or with a permanent residence permit) as well as tax non-residents. Likewise, taxpayers of corporate income tax are legal subjects (and other subjects as defined by law, e.g. trust funds), regardless of their residence or the residence of their management.

It is noteworthy that the Act did not impose the obligation to register sales on all the subjects at the same time; on the contrary, there are four stages. The first stage (starting on 1 December 2016) made Registration compulsory for entrepreneurs dealing with accommodation and food service activities. The second stage (starting on 1 March 2017) included wholesale and retail trade. The third stage (planned to become effective from 1 March 2018) should involve all subjects excluding those that fall into the fourth stage (starting on 1 June 2018), which should include selected crafts and manufacturing activities (e.g. textile production, furniture production, specialized building activities).

The range of taxpayers obliged to register sales is rather wide. It is estimated that Registration will involve approximately 600,000 entrepreneurial and other subjects and in one way or another, approximately 2 million people will come into contact with it. It is also estimated that around 30 million transactions will be 
registered daily, which means that annually there will be around 11 billion bilateral transactions between the state and taxable subjects. Some even claim the total figure per year might reach 18 billion (Hajdušek, Vodička, 2017). These estimates cannot be tested now since the system of Registration with its four stages does not involve all taxable subjects. In August 2017 the Ministry of Finance registered almost 1.7 billion sales with the total sum of almost 600 billion. By then almost 151000 entities had entered the system and the system at its height processed 1.5 million sales per hour (Žurovec, 2017a).

\subsection{Subject Matter of Registration}

The subject matter of Registration are sales with two important elements:

1. The sale was made in accordance with the conditions stipulated by law (material element),

2. The sale was made using the designated method (formal element) (Explanatory note, Parliamentary press no. 513).

The formal element is accomplished if the payment is made in cash, by a cashless transfer of funds (credit card), by cheque, by the promissory note, or in other forms (virtual currency, food vouchers, and gift vouchers). Transactions made from one bank account to another are thus exempt from Registration.

As far as the material element is concerned, the Income Tax Act was used again. Registration is therefore compulsory for the type of entrepreneurial income that is subject to the income tax. It is not therefore necessary to register income gained by being employed or rental income. Similarly, it is not necessary to register payments that are, given the nature of usually accepted payments, exceptional.

It is also worth pointing out that Sec. 12 of the Act lists payments that are exempt from Registration (e.g. sales achieved by the state, territorial self-governing authorities, banks, insurance companies, from a fare in the public transport, on board an aircraft, or from the operation of public toilets).

If subjects are not sure whether the payment that is being accepted qualifies as a registered sale, they may ask the tax authority for a binding ruling, in which the tax authority states whether the given sale is a registered one or not (Sec. 36 of the Act).

\subsection{Registration Methods}

The most common method is the 'standard regime' described in detail above. Under this regime, a taxable subject sends payment details electronically to the Financial 
Administration, which then sends back an FIC. This code is then printed on the receipt offered to the customer. However, there are also exceptional circumstances that allow a receipt to be printed even without the FIC. Firstly, this is possible under the so-called "simplified regime". Secondly, one may print a receipt without the FIC in case it is not possible (mostly due to technical issues) to connect to the Financial Administration portal; hence the FIC cannot be obtained.

\subsection{Simplified Regime}

The "simplified regime" method of Registration was introduced mainly because of those subjects without continuous access to the internet. Under this regime, only sales stipulated by the Act or in governmental orders can be registered as well as those sales that have been approved (at the request of the entrepreneur) by the tax authority. The Act stipulates that simplified regime can be applied to both sales of goods and services on board of a vehicle during regular public transport and sales whose registration under the standard regime would prevent or significantly complicate the smooth and efficient conduct of the business from which these sales originate.

The simplified regime allows entrepreneurs not to send details of every single sale immediately at the time of the transaction to the Financial Administration portal. The accepted payments are stored in the memory of the device and must be sent to the Financial Administration portal in bulk within five days. The simplified regime is illustrated below.

\section{Graph 2 System functioning of Registration in case of simplified Regime}

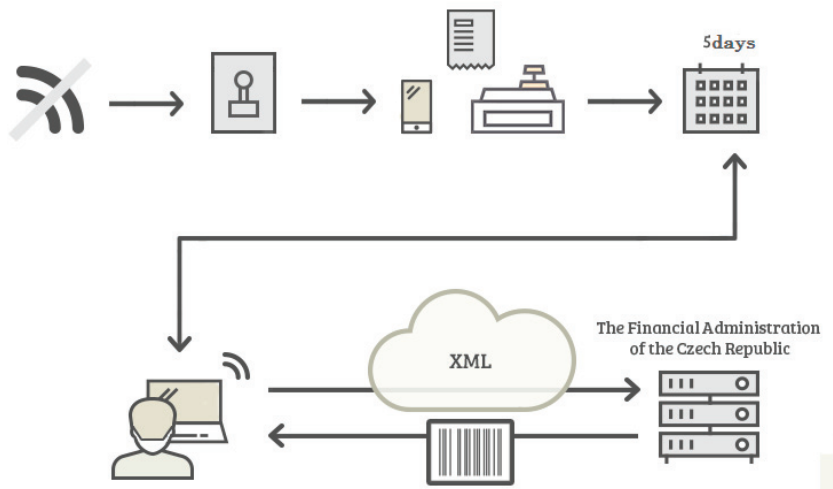

Source: www.etrzby.cz. 


\subsection{Problems with Online Registration}

Problems with online Registration are caused particularly by technological issues (e.g. a short-term internet failure). These prevent immediate connection to the Financial Administration portal; therefore the FIC cannot be obtained. In order to avoid prolongation of a business transaction (which is clearly highly unpleasant and uneconomical for both the customer and the seller), the Act also permits to finish transactions without obtaining the FIC. The FIC is not necessary if the socalled "response time limit" is exceeded. The response time is a period of time between the attempt to send registered sale details from the taxpayer's device and the appearance of the FIC on the same device. The response time limit is set by the registering subject, often with regard to the connection speed and its quality. If the limit is exceeded, the registering subject is permitted to print a receipt even without the FIC, thereby finalizing the transaction without being connected to the Financial Administration portal. The missing payment details must then be sent to the tax authority within 48 hours. This legislative measure should allay the fears that Registration will prolong the amount of time spent in shops and will thus lead to big queues. As regards the response time, the Ministry of Finance claims that the average response time in June 2017 was approximately one-tenth of a second. This figure was also confirmed by independent checks (Žurovec, 2017a). The system described verbally above can be illustrated as follows.

\section{Graph 3 System functioning of Registration in case of problems with online connection}

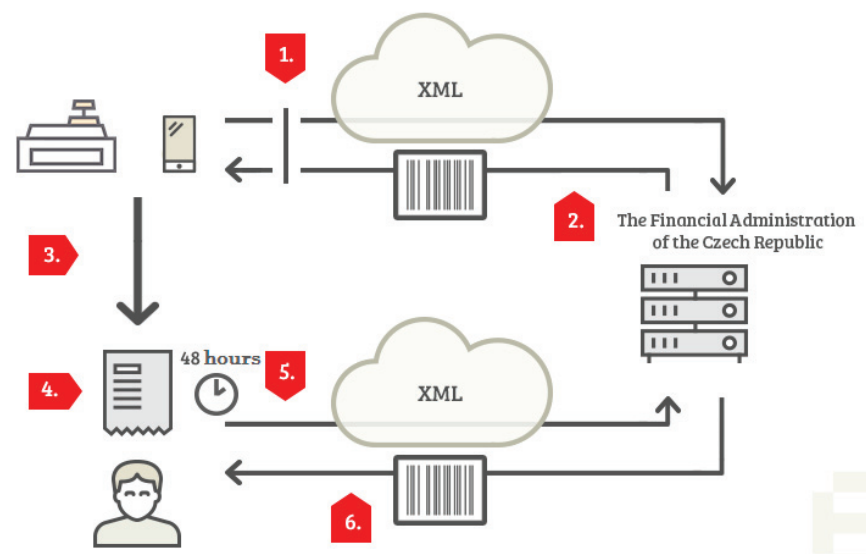

Source: www.etrzby.cz. 
Electronic Registration of Sales in the Czech Republic - Theory and Praxis

\subsection{Supervision of Compliance with Obligations Stipulated by the Act}

Registration is based, among other things, on strict supervision of compliance with obligations. What is rather unusual about Registration is the fact that supervision is not carried out by a public authority only, but also by the public itself.

\subsection{Supervision - the Public}

As has been stated above, every customer holding a receipt with an FIC can then check at the Financial Administration portal whether the sale has indeed been registered with the tax authority by the entrepreneur. Customers' motivation to check registered sales should increase with the arrival of the so-called "receipt lottery", which exists for example in Croatia, Slovenia, and Taiwan. The Act states that the public can enter the lottery by sending in the receipt or by sending the data printed on the receipt (Snopková, 2016: 409-423). In return, the public can win prizes or money. The latest news has it that the lottery should be launched at the beginning of October 2017. Annually, the Ministry of Finance will hand out money and prizes worth CZK 65 million $\left(1^{\text {st }}\right.$ prize: CZK 1 million, $2^{\text {nd }}$ prize: a car worth CZK 400,000, $3^{\text {rd }}$ prize: CZK 300,000) (Vlková, 2017). The lottery will take place every month and it will include receipts from a previously indicated period. The customer may only register one receipt from one seller per day (Žurovec, 2017). The receipt lottery can be regarded as a rather unusual though possibly an effective way to check registered sales. One may ask, however, if the receipt lottery should not give prizes also to subjects that comply with all the obligations connected with Registration.

\subsection{Supervision - State Authorities}

The system of Registration is checked not only by the public but also by state authorities. The Act states that supervisory bodies include the Czech Financial Administration as well as Customs Administration authorities. When carrying out supervision they follow Tax Code, no. 280/2009. Typically, such supervision involves the inspection of data messages with payment details, issuing receipts and putting up information posters. The supervision is carried out by means of a feigned purchase.

Local supervision is performed by officers on location, i.e. where Registration should take place according to the Act (typically in the shop). Such supervision may only involve observation, and if no breach of regulations is revealed, officers may not even reveal their true identity. In such cases, officers simply fill out an official report, which is then filed. Alternatively, officers may feign a purchase, i.e. 
they behave as regular customers and they observe what the entrepreneur does and whether he or she registers the sale. Providing the nature of the feigned purchase allows it, officers may back out of the contract and they should be refunded for the goods they have purchased. This is sometimes not possible: if the back-out goes against the nature of the feigned purchase (typically if the subject matter has been consumed, e.g. getting a haircut at the hairdressers) or if the back-out causes material harm to the taxpayer (if the subject matter is destroyed, e.g. buying food at a takeaway) (Explanatory note, Parliamentary press no. 513). The back-out can be done after the officers have revealed their true identity; the feigned purchase and the local supervision activity are then described in an official report (Hajdušek, Vodička, 2017: 57-58).

The latest data maintains that within the first eight months of Registration almost 50,000 inspections were carried out; $15 \%$ of which discovered some errors (Padla dosud nejvyšší pokuta kvůli EET, 2017).

\subsection{Administrative Misdemeanours}

In case an error has been discovered, the tax authority carrying out supervision initiates an administrative action against the taxpayer accused of committing an administrative misdemeanor. The taxpayer receives an official notice about the action; he or she can then express their opinion and suggest evidence in their favor within a given period (Hajdušek, Vodička, 2017: 60-61).

The Act stipulates relatively only a few elements of the crime, which the Act describes rather vaguely so that a wide range of specific errors can fall within this category. The Act deals in particular with entrepreneurs that completely fail to obey the law: he or she does not register sales, data messages payment details are not sent to the tax authority, receipts are not issued at the time of purchase and posters with information about the need to register sales are not put up. All these misdemeanors (apart from the last one) can result in a fine worth up to CZK 500,000. The Authors are convinced that such a wide range of potential fines along with the vaguelystipulated elements of the crime are rather unfortunate for the tax authority and the entrepreneur alike. As has been indicated above, Registration is a new component in Czech law and, as such, it is a new aspect in the area of administrative penalization. This can pose a problem or two especially for the tax authority, which (if errors are discovered) must be able to levy adequate fines in specific cases, taking into account all the mitigating and aggravating circumstances, the current status of the offender (their prior conduct and their current status) as well as other relevant facts. 
The latest data published by the Financial Administration informs us that the average fine imposed in an administrative action is about CZK 15,000 (Padla dosud nejvyšší pokuta kvůli EET, 2017).

\section{The Registration - Goals and their Fulfilment}

As has been stated above, the Act was approved with the aim 'of leveling unlawful competitive advantage of taxpayers failing to pay taxes properly and of increasing public budgets'. The expected increase of tax collection after the introduction of Registration was derived from the situation in Croatia (whose legislation served as a model for Czech Registration - see below); the explanatory report asserts that the annual increase should reach CZK 12.5 billion (Explanatory note, Parliamentary press no. 513). In January 2017 the Financial Administration announced that in the previous month (December 2016, the first month of Registration) the increase of tax collection was 100\% (Ťopek, 2017). This information is of little value though as the short period of operation only allowed a small sample of entrepreneurs to be involved (approximately 1,600) (Čísla Finanční správy o růstu tržeb se oproti číslům ČSÚ liší, není to překvapivé, 2017). Another partially usable fact is the information that in comparison with the year of 2016, by the end of July 2017 the value added tax (hereafter referred to as the VAT) collection had increased by CZK 14.4 billion (an increase of 11.2\%). Since April 2017 the VAT has been on the increase by double figures, despite the fact that the increase of final consumption (which significantly affects the collection of the VAT) has only been estimated to be at $6 \%$. The Ministry of Finance is convinced that the increase of the VAT has been caused by, among other things, Registration (Žurovec, 2017b). We would like to point out that the aforementioned increase of the VAT collection happened in spite of the fact that the VAT rate in area of food service had been lowered from $21 \%$ to $15 \%$ (like in Croatian law where the VAT had dropped from 25\% to 17\%) (Kudeljan, 2015).

One may agree with the General Financial Director, who asserts that because of the length of the taxable period further analyses of the influence of Registration on the state budget will occur after a longer period of time elapses (Ťopek, 2017). In August 2017 the spokesperson of the Financial Administration announced that the Financial Administration was admittedly analysing the data but it did not have any estimates regarding Registration and its influence.

As far as another objective of Registration is concerned, namely the one regarding the level playing field for entrepreneurs, there is no undisputable data available at the moment. Nonetheless, the spokesperson of the Czech Chamber of Commerce announced in August 2017 that it was certain that Registration had eliminated at least part of the competitive advantages that unfair entrepreneurs had had over 
the ones who obeyed all the regulations. Furthermore, we want to cite the head of the Czech Association of Traditional Commerce, who claims that there has been no dramatic increase in the bankruptcies of small shops, as had been envisaged by some experts. He maintains that only a few dozens of shops have been closed down because of Registration (První měsíce provozu EET přinesly pokuty za devět milionů, 2017).

Apart from increasing the public budget and levelling the playing field for entrepreneurs, the Financial Administration hopes that Registration will help to achieve other positive goals: as the possibility of using the gathered data by entrepreneurs, quicker and more accurate reactions to unfair conduct, lower tax burden in the future, targeting tax inspection at only those subjects that submit dubious data and the subsequent lowering of burden for dutiful taxable subjects (Proč evidence tržeb?). The last of the goals mentioned above has been confirmed by the Minister of Finance, who believes that in the future the number of tax inspections will decrease, because these inspections will focus on dishonest subjects only (Evidence tržeb v praxi. Úvod, 2016). At the moment there is no data available to confirm or refute these proclaimed goals of Registration.

\section{Comparison with Other Countries}

The Czech system of Registration was devised according to the 'fiscalization' model that has been in use in Croatia since 1 January 2013 (Explanatory note, Parliamentary press no. 513). Croatian legislation served as a model for the Registration method itself (sending payment details online to the financial authority, accepting the code, issuing the receipt and checking the registered receipt). There are, however, some differences as well: Croatian legislation insists that the customer accepts the receipt and has it while leaving the shop. This option was weighed up by Czech legislators but it was not accepted eventually (Hornochová, 2015). Some Authors draw attention to the fact that the absence of such an obligation may open the door for evasion based on a mutual agreement between the customer and the seller, or on the same receipt being presented over and over again (Radvan, Kappel, 2016: 334-356). Another difference lies in the amount of data that is required by the Financial Administration (there is much more data required in Croatia). Yet another difference can be found in the system of fines, more specifically in the maximum amount of money that can be imposed in case of a breach of regulations linked with Registration. Both countries can impose fines of up to 500,000 of the local currency (HRK 1 is roughly CZK 3.50) (Fiskalizace v Chorvatské republice: fakta, 2016). One more difference concerns the fact that, unlike Czech law, Croatian law charges the Authorisation certificate for the use of Registration - it costs HRK 300 
for the period of five years (i.e. HRK 60 per year) (Fiskalization, 2012). Finally, the Croatian "simplified regime" of registration is somewhat different as it is based on numbered sheets of paper that are registered in advance by the tax authority and then are filled in by hand by the seller (Hornochová, 2015).

Except for the Czech Republic and Croatia, a certain form of registration of sales is used in other European countries, too: according to the official information about Registration that is available online the following countries use it: Italy, Hungary, Slovakia $^{4}$, Poland, Belgium, Lithuania, Latvia, Malta, Sweden, Romania, Bulgaria, Greece, Cyprus, Austria and Slovenia) (Zkušenosti ze zahraničí, 2016). The most common type is offline cash registers where payment details are entered in an unalterable form; these are not, however, sent online immediately to the financial administration. This system can be found in e.g. Belgium, Poland and Austria. Some legislation (e.g. in Hungary) enable a "hybrid" type of sales registration - data messages are not sent immediately but at regular intervals. Apart from Croatia, the type of electronic sales registration that can be found in the Czech Republic also exists in Slovenia (Smetanková, Palán, 2015).

\section{Conclusions}

This paper deals with Registration that has been in use in the Czech Republic since 1 December 2016. The main focus is on the basic aspects of the system such as the operation of the system, taxable subjects that need to register their sales, registered sales, registration methods and the supervision of compliance with registration obligations. A separate chapter discusses the objectives of the new legislation and the relevant data available to date. From a comparative perspective, this paper briefly described systems of sales registration in other countries, with particular attention drawn to Croatia, which served as the model for the Czech system of Registration.

The Authors believe that Czech legislation took a step in the right direction when it refused certified cash registers that exist in many other countries. As far as the required technology is concerned, a device capable of electronic communication via the internet is the only thing that is needed (it might be e.g. a PC, tablet, mobile phone, cash register, other cash systems, etc.). Such a device must be connected to the internet when a payment is being accepted. It is up to the entrepreneur to choose the optimal type of device along with the most suitable software according

4 A certain type of cash registers was introduced in Slovakia in 1995, since then the Slovakian Financial Administration has been introducing stricter and stricter obligation regarding the Registration. In 2009 Slovakia introduced the obligation to use offline electronic cash registers with a fiscal memory; in April 2015 the system was changed to such an extent that certain service providers can either carry on using the existing cash registers or they can join the "virtual cash register" online (very much like in the Czech Republic). 
to the type of service provided or activity performed. The crucial thing is that data messages with payment details are sent and receipts are issued. In other words, there is no need to buy a specialized certified cash register.

The comparison with Croatian legislation also reveals the fact that Czech legislation opted for an approach that is less demanding for the recipients of the norm. The Czech legislation does not include the obligation for customers to accept receipts, nor does it include the obligation for taxable subjects to pay for certification details. In addition, the amount of data sent to the Financial Administration is not as high as it is in Croatia. On the one hand, such a less strict approach can lead to a certain lack of effectiveness of Registration, but on the other hand, it results in a more positive acceptance of it on the part of the public, and a smoother way of putting the system into practice (it is worth pointing out that in 2016 the Act finished second in the Best Piece of Legislation competition, thanks to the votes from entrepreneurs and the public alike) (Žurovec, 2017a).

The Authors believe that an even more positive acceptance of the system could be ensured by other legislative aspects: the option to print receipts even without being connected to the Financial Administration portal, the simplified regime, lower VAT in the area of food service, the introduction of income tax deduction of up to CZK 5,000 for natural persons as compensation for initial costs connected with the Registration, and the receipt lottery.

The Authors are convinced that all the information above confirms the hypothesis put forward at the beginning (namely that Registration is an effective measure against tax evasion). It is beyond doubt that Registration enables the Financial Administration immediate access to all sales made by taxable subjects. This very fact (providing that the Financial Administration analyses the data correctly) should enable a growing awareness of tax liability of individual subjects. Another indisputable fact is that Registration is a strong preventive measure against unlawful sales reduction by taxpayers. Prevention is also achieved by means of supervisory and enforcing mechanisms included in the Act. The latest data suggest that these mechanisms (a feigned purchase, fines, etc.) are actively used by the Financial Administration, thereby making the system more effective.

The effective operation of Registration is also confirmed by growing VAT revenues. It must be added though that the data is not complete (due to the short period of time since Registration was introduced and due to the gradual four-stage implementation of the system) and the conclusion regarding the increase of revenues in public budgets cannot, therefore, be proved beyond doubt. Similarly, it is rather difficult to predict whether the other intended objectives of Registration will be accomplished 
Electronic Registration of Sales in the Czech Republic - Theory and Praxis

(e.g. a level playing field in the business environment and a sharper focus of tax inspections).

As regards the future of the Registration, we cannot but wait for more complete and relevant data that should enable a more accurate analysis of the system and its effects. It is hoped by the Authors that the Financial Administration in close co-operation with taxable subjects will keep amending legislation to meet the demands of the real-life business environment (lately, the Ministry of Finance has proposed exemption from Registration for the visually impaired until there is a cash device that is technologically suitable for people with such a disability). Nevertheless, it must be stressed that even though future legislative changes will be necessary, the effectiveness of the system will only be ensured if the obligation to register sales will involve as wide a range of taxable subjects as possible. The Authors also maintain that positive motivation for subjects obliged to register sales would be beneficial, too - this could be done, for instance, by their inclusion in the receipt lottery. Another de lege ferenda suggestion is to introduce a more precise specification of the system of fines.

In conclusion, the Authors consider Registration an effective way to monitor the number of sales made by taxable subjects. As long as the Financial Administration keeps conducting inspections and keeps performing systematic data analyses, and as long as the system is not weakened by a great number of exceptions, it may be expected that Registration will fulfill the objectives intended by the legislation.

\section{References}

Hajdušek, T. et al.: První zkušenosti s EET - elektronickou evidencí tržeb (First experience with ROS - registration of sales), Prague: Wolters Kluwer, 2017.

Hornochová, S.: Př́spěvek Simony Hornochové - Konference o EET (Contribution of Simona Hornochová - Conference of ROS), 2015. www.youtube.com.

Kudeljan, V.M.: Příspěvek M.V. Kudeljan - Konference o EET (Contribution of M.V. Kudeljan Conference of ROS), 2015. www.youtube.com.

Radvan, M. et al.: Elektronická evidence tržeb jako nástroj kontroly v berním právu (Registration of Sales as a Control Instrument in Tax Law), in: Mrkývka, P. et al. (eds.): Dohled, dozor, kontrola ve veřejné finanční činnosti (Surveillance, supervision, control of public financial activities), Brno: Masarykova univerzita, 2016.

Smetanková, D. et al.: Právní úprava evidence tržeb ve vybraných zemích EU (Legal registration of sales in selected EU countries). Prague: Parliament Institute, 2015.

Snopková, P.: Uplatnění kontrolních mechanismů $\mathrm{v}$ rámci daně z přidané hodnoty (Apply of Controlling Mechanisms within the Scope of Value Added Tax), in: Mrkývka, P. et al. (eds.): 
Dohled, dozor, kontrola ve veřejné finanční činnosti (Surveillance, supervision, control of public financial activities), Brno: Masarykova Univerzita, 2016.

Ťopek, M.: Z EET si nikdo nebude dělat srandu, říká šéf Finanční správy (No one will be kidding from the ROS, says the head of the Financial Administration), 2017. www.financnisprava.cz.

Vlková, J.: Účtenkovou loterii chce ministerstvo stihnout ještě před volbami (The ministry wants the receipt lottery to run before the election), 2017. www.ekonomika.idnes.cz.

Žurovec, M.: Podnikatelé a odborníci rozhodli: Elektronická evidence tržeb je druhým nejlepším zákonem roku 2016 (Entrepreneurs and experts have decided: Registration of Sales is the second-best law in 2016), Praha: Ministry of Finance, 2017a. www.mfcr.cz.

Žurovec, M.: Státní rozpočet je po sedmi měsících v přebytku 25 mld. Kč (The state budget is in surplus of CZK 25 billion after seven months), Praha: Ministry of Finance, 2017b. www. mfcr.cz.

Žurovec, M.: Účtenková loterie má svého dodavatele (The receipt lottery has its supplier), Prague: Ministry of Finance, 2017. www.mfcr.cz.

Čísla Finanční správy o růstu tržeb se oproti číslům ČSÚ liší, není to překvapivé (The Financial Administration's numbers of revenue growth are different from those of CSO, it's not suprising), 2017. www.etrzby.cz.

Explanatory note to the Bill on Registration of Sales, Parliamentary press no. 513, 2015. www.psp.cz.

Evidence tržeb v praxi. Úvod (Registration of Sales in praxis. Introduction, 2015. www.youtube.com.

Fiskalizace v Chorvatské republice: fakta (Fiscalization in Croatia: facts), 2016. www.etrzby.cz.

Fiskalization in HR: Questions \& Answers, 2012. www.fiscalization.hr.

Padla dosud nejvyšší pokuta kvůli EET (The highest penalty yet has been imposed because of ROS) Úřady proti nepoctivcům přitvrdily (authorities tightened against non-honest people), 2017. www.ekonomika.idnes.cz.

Proč evidence tržeb? (Why registration of sales?). www.etrzby.cz.

První měsíce provozu EET přinesly pokuty za devět milionů (First months of operation of ROS brought fines for nine million), 2017. www.businessinfo.cz.

Zkušenosti ze zahraničí (Experience from abroad), 2016. www.etrzby.cz.

CZ: Tax Code, no. 280/2009, as amended.

CZ: Act no. 112/2016, on Registration of Sales, as amended.

CZ: Act no. 586/1992, on Income Taxes, as amended. 